\title{
Radiative fluxes and their impact on the energy balance of the Greenland ice sheet
}

\author{
Thomas Konzelmann and Atsumu Ohmura \\ Geographisches Institut, Eidgenössische Technische Hochschule (ETH), CH-8057 Zürich, Switzerland
}

\begin{abstract}
A meteorological experiment was carried out during the summer months of 1990 and 1991 near the mean equilibrium-line altitude (ELA) on the western slope of the Greenland ice sheet (ETH Camp; $69^{\circ} 34^{\prime} \mathrm{N}, 49^{\circ} 17^{\prime} \mathrm{W}$; $1155 \mathrm{~m}$ a.s.l. .). As a part of the project, the energy fluxes at the surface, including all components of the radiation balance, atmospheric profiles with a tower and radiosondes, and the cloud conditions were investigated in detail. Results from the radiative fluxes are compared with observations made at other locations in order to derive general characteristics of the radiation conditions on the Greenland ice sheet and their relation to the climate of the ice sheet.

At ETH Camp, albedo values obtained at ground level $(2 \mathrm{~m})$ and from a high tower $(27 \mathrm{~m})$ are similar during the melt season (late May to mid-August) and slightly different during pre- and post-melt seasons due to the interplay of inhomogeneous surface conditions and solar elevation. During the melt period, the decrease in global radiation due to increasing cloud amount is compensated for by an increase in longwave incoming radiation. Because of the steady values of longwave outgoing radiation, net radiation at the surface is characterized mainly by the albedo and its variation. The regional net radiation for summer months on the Greenland ice sheet is determined mainly by three facts: (1) a strong increase in albedo from the ablation area to the ELA and a smaller increase from the ELA to the accumulation area; (2) a large increase in longwave outgoing radiation in the ablation area and at the ELA in June and July compared to the accumulation area; (3) a larger amount of cloud of the stratus type at lower areas.
\end{abstract}

\section{INTRODUCTION}

Because of the large surface area of the Greenland ice sheet and its impact on the regional and global climate, energy-balance investigations on the Greenland ice sheet became necessary. These include knowledge of the structure of the atmosphere above the ice sheet as well as the physical processes at the surface and in the snow and ice layers. In contrast to Antarctica, where the air temperature is very low, large areas of the Greenland ice sheet are subject to intense melting during summer and a global warming will probably enlarge such areas with an increasing rate of melt. Only with a thorough understanding of the atmospheric boundary layer and the energy- and mass-exchange processes can the response of the Greenland ice sheet to changing climatic conditions be simulated by thermodynamic ice-sheet models (Huybrechts and others, 1991; Abe-Ouchi and others, 1994).

The energy balance, which includes net radiation, sensible-heat flux, latent-heat flux, latent heat of fusion and ground-heat flux, determines the melt processes at the surface. These processes depend strongly on atmospheric conditions and surface properties. The energy gain at the surface is caused mainly by the radiation balance during the melt season, because the sensible- and latent- heat flux almost cancel out each other (Ambach, 1963; Ohmura and others, 1994). This energy is mainly used to melt snow and ice. Therefore, a detailed knowledge of all components of the radiation balance and their interactions is necessary.

The Greenland ice sheet is the only ice sheet in the Northern Hemisphere and it presently stores $8 \%$ of the global ice volume (Ohmura, 1987). The climate of the mean equilibrium-line altitude (ELA) can be regarded as the representative climate for the ice sheet (Ohmura and others, 1992a). Therefore, the present study site (ETH Camp; $69^{\circ} 34^{\prime} \mathrm{N}, 49^{\circ} 17^{\prime} \mathrm{W} ; 1155 \mathrm{~m}$ a.s.l.) is located near the ELA (Fig. 1). The area surrounding the site is a flat snow and ice plain and deviates less than $1^{\circ}$ from an ideal horizon (Laternser, 1991). Meteorological measurements, including upper-air sounding, air temperature, relative humidity, wind speed, wind direction, radiative and turbulent fluxes, temperature profiles in the snow and ice layers, mass balance and synoptic observations were carried out and have been described in detail by Ohmura and others (1991, 1992b). These measurements were prepared to improve the understanding of the climatic conditions and the exchange processes at the surface, which take place from the free atmosphere through the atmospheric boundary layer into the snow and ice layers.

The present paper shows the interactions of radiative 


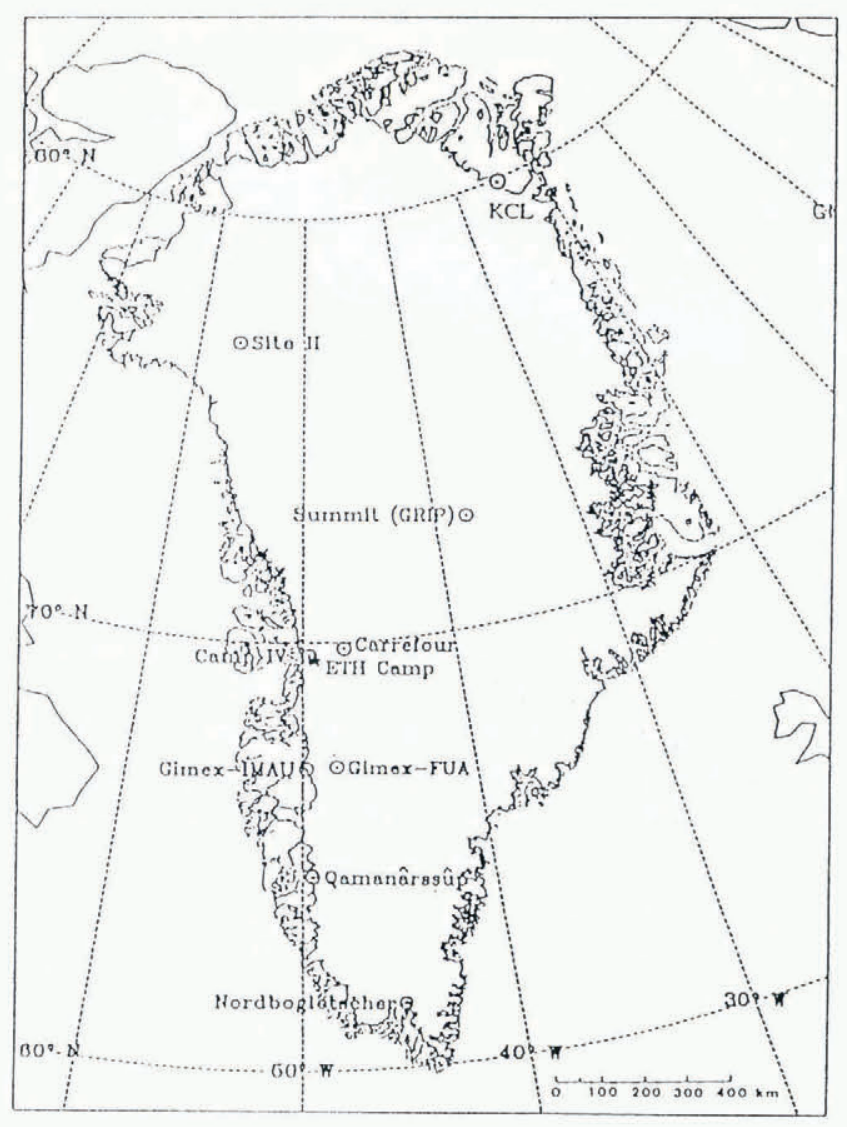

Fig. 1. Locations of radiation measurement on the Greenland ice sheet referred to in the text. Solid line, ice margin.

fluxes and atmospheric and surface conditions which can be used to improve existing parameterization schemes of shortwave and longwave radiative fluxes as well as to provide the ground truth for remote sensing and the validation for general circulation models (GCMs).

\section{METHODS AND INSTRUMENTATION}

At ETH Camp, the following radiative fluxes were determined for the periods 6 June 29 August 1990 and 11 May-27 August 1991: direct solar radiation, diffuse sky radiation, global radiation, shortwave reflected radiation, longwave incoming radiation, longwave outgoing radiation and net radiation. The albedo was obtained at ground level $(2 \mathrm{~m})$ and from a high tower $(27 \mathrm{~m})$. Detailed cloud observations (amount and type) were made seven times a day. A list containing the time series of the amount of each of the following cloud types was compiled: low cloud as cumulus, stratocumulus, stratus; middle cloud as altocumulus translucidus, altostratus translucidus, altostratus opacus; high clouds as cirrus, cirrocumulus, cirrostratus. The cloud observations were based on the codes of the World Meteorological Organization (WMO).

The radiation balance can be expressed by the following equation:

$$
N R=(Q+q)(1-\alpha)+\left(L_{\mathrm{i}}-L_{\mathrm{o}}\right) .
$$

In addition to the net radiation measured by a net radiometer, the individual components were observed. The measured components were global radiation $G L=$ $Q+q)$, diffuse sky radiation $(q)$, shortwave reflected radiation $(\alpha G L)$ at ground level and from the high tower, all-wave sky radiation (diffuse sky and longwave incoming radiation, $A W_{\text {dif }}$ ), all-wave outgoing radiation (shortwave reflected and longwave outgoing radiation. $\left.A W_{\text {out }}\right)$ and net radiation $\left(N R_{\mathrm{m}}\right)$. Direct solar radiation $Q$ ) was calculated as the difference between global radiation and diffuse sky radiation. Additionally, direct solar radiation $\left(Q_{\mathrm{m}}\right)$ was measured by an Eppley NIP in 1991. Longwave incoming $\left(L_{\mathrm{i}}\right)$ and outgoing $\left(L_{\mathrm{o}}\right)$ components were calculated as follows:

$$
\begin{aligned}
& L_{\mathrm{i}}=A W_{\text {dif }}-q+\sigma T_{\mathrm{u}}{ }^{4} \\
& L_{\mathrm{o}}=A W_{\text {out }}-\alpha G L+\sigma T_{\mathrm{d}}{ }^{4}
\end{aligned}
$$

where $T_{\mathrm{u}}$ and $T_{\mathrm{d}}$ are the body temperatures in Kelvin of the up-facing and the down-facing sensors, respectively. They are measured with $\mathrm{Pt}-100$ resistance thermometers. $\sigma$ is the Stefan-Boltzmann constant $\left(=5.67 \times 10^{-8} \mathrm{~W} \mathrm{~m}^{-2}\right.$ $\left.\mathrm{K}^{4}\right)$. The emissivity of the sensor surface was assumed to be unity.

The site was equipped with four pyranometers (Swissteco, SS-25), two pyrradiometers (Swissteco, ST25), a net radiometer (Swissteco, S-1) and a pyrheliometer (Eppley, NIP). The pyrheliometer was mounted on an electrically driven sun tracker. Two pyranometers were used for measuring $G L$ and $\alpha G L$ at ground level $(2 \mathrm{~m})$. The third pyranometer was mounted on the micrometeorological tower, at a height of $27 \mathrm{~m}$ for measuring shortwave reflected radiation representative of a larger area. The fourth pyranometer was mounted as a diffusograph with a shading ring (shading angle of $\left.121^{\circ}\right)$. The up-facing pyrradiometer was also equipped with a shading ring, exactly in the same manner as the diffusograph. The quality of the results can be improved considerably by using the shading method Ohmura and Schroff, 1983; DeLuisi and others, 1993). The downfacing pyranometer at ground level, the down-facing pyrradiometer and the net radiometer were mounted close to each other on a $2 \mathrm{~m}$ long horizontal bar on the same stage so that the measurements from the instruments represented the same undisturbed surface conditions. The sensors with the shading rings and the up-facing pyranometer $(G L)$ were mounted on separate stages. The stages were drilled into the ice about $35 \mathrm{~m}$ southeast (up-wind) of the camp and the horizontal distance between the instruments was about $4 \mathrm{~m}$. All the instruments were mounted on average between $1.4 \mathrm{~m}$ and $2.0 \mathrm{~m}$ above the surface and fixed from time to time at a lower level because of the melting surface. The down-facing pyranometer on the tower was fixed at a distance of $2.5 \mathrm{~m}$ from the frame of the tower at a height of $27 \mathrm{~m}$. At least four times a day $(0000,0600,1200$ and $1800 \mathrm{~h} \mathrm{UTC}$ ) all the conditions of the instruments were checked and the shading rings were turned to follow the path of the Sun. The signals from the radiometers were recorded every $15 \mathrm{~s}$, averaged over a $30 \mathrm{~min}$ period and stored in a data logger.

During the three periods, at the beginning, in the middle and at the end of each field season, relative calibrations were made, where all sensors were mounted 
up-facing and the shading rings were removed. For the relative calibration, one pyranometer was chosen as a reference instrument and the values of the other pyranometers were adapted to the reference instrument by linear functions. The cut-off by the shading rings was calculated after Drummond (1956) and corrected accordingly. For the all-wave sky radiation, only part of the shortwave radiation was corrected. The error in the up-facing pyranometer $(G L)$ due to the cosine response was corrected for zenith angle $>70^{\circ}$ using a polynominal function whereby only part of the direct solar radiation $G L$ was taken into account.

The calibration coefficients are those in World Radiometric Reference (WRR). All sensors were calibrated by the manufacturer less than 1 year prior to use in the field season 1990. In addition, three pyranometers global radiation, diffuse sky radiation and shortwave reflected radiation at ground level) were recalibrated after the field seasons with a PMO6 absolute radiometer in combination with a shaded reference pyranometer. One pyrradiometer was recalibrated under an ice cavity at the melting point.

The uncertainties in the pyranometers are about $\pm 4 \mathrm{~W} \mathrm{~m}{ }^{2}$. This value is derived by absolute and relative calibrations. The uncertainty of the longwave incoming radiation using the shading method is estimated at $\pm 10 \mathrm{~W} \mathrm{~m}^{-2}$ according to an intercomparison of instruments performed by DeLuisi and others (1993). The evaluation of the longwave outgoing radiation is more accurate due to melting surface conditions. The uncertainty of the calculated net radiation $\left(N R_{\mathrm{c}}\right)$ is estimated at $\pm 12 \mathrm{Wm}^{-2}$.

\section{RESULTS}

The results presented here were obtained during the summer months June, July and August. In 1990, measurements started at the onset of melt and stopped in the post-melt season, while the observations in 1991 include pre-melt (May), melt and post-melt seasons.

\section{Measuring discrepancy}

At the present site, net radiation was measured directly with a single net radiometer $\left(N R_{\mathrm{m}}\right)$ and also calculated $\left(N R_{\mathrm{c}}\right)$ as the sum of shortwave and longwave radiative fluxes which were individually measured. In Figure 2 the difference between $N R_{\mathrm{c}}$ and $N R_{\mathrm{m}}(\Delta N R)$ is plotted against global radiation. The circles represent hourly mean values 1909 cases) for the summer months of 1990 . The comparison shows a significant underestimation of net radiation measured by the Funk-type net radiometer. Müller and Ohmura (1993) showed a similar characteristic for measurements made at Payerne (Switzerland) with the same type of instrument. They reasoned that, when the sensor surface is heated by solar radiation i.e. the net-radiometer output is positive), the net radiometer loses a part of the absorbed radiation to thermal convection which develops between the sensor surface and the polyethylene dome. The best fit between the underestimation of net radiation and global radiation can be obtained using a function described by the following:

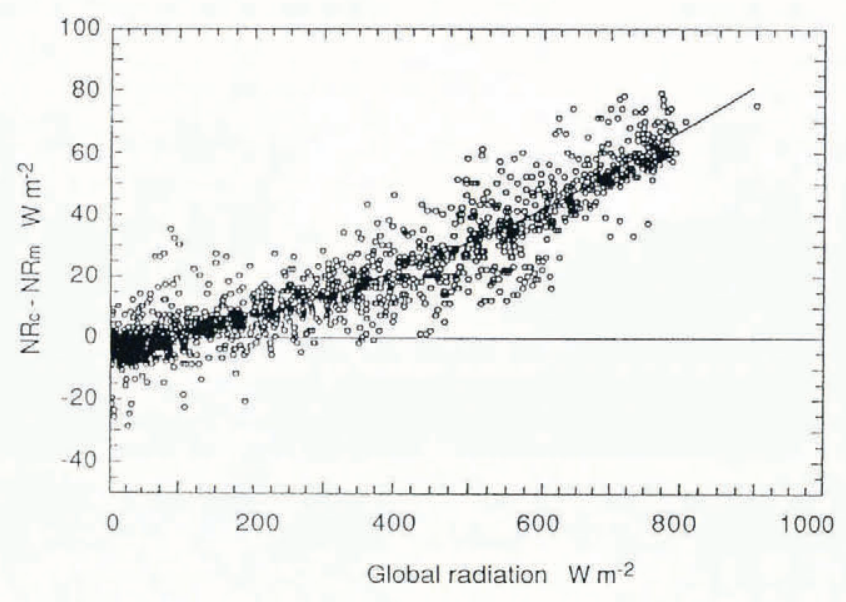

Fig. 2. Relationship between the difference in net radiation $\left(\mathcal{N} R_{c}-\mathcal{N} R_{m}\right)$ and global radiation based on hourly mean values of summer months 1990. $N R_{c}$ is calculated as the sum of shortwave net and longwave net radiation. $N R_{m}$ is measured directly. The curve represents the optimal fit of Equation (4) to the points shown in the figure.

$$
\Delta N R=a G L^{b}
$$

with $a=0.00125$ and $b=1.6297$. The comparison between ETH Camp and Payerne indicates that the amounts of $\Delta N R$ are similar during the summer season for a mid-latitude station and a station on the Greenland ice sheet. It is a matter for further investigation whether this conclusion can be treated as generally valid or whether there is a dependence on the type of instrument used in both studies. As shown by Halldin and Lindroth (1992), a large variation can be expected by comparing different types of net radiometer. In the present work, the calculated net radiation, i.e. the sum of the individual components, is used.

\section{Cloud conditions}

As cloud conditions strongly influence radiative fluxes at the surface, the cloud observation is presented first. Because of the individual differences in the estimation and the interpretation of cloud amount and types, systematic errors in the observations are unavoidable (e.g. Warren and others, 1985). The quality of data for low cloud is better than for middle and high clouds, because the observations were made at ground level and so the recording of middle and high clouds was affected by the amount and frequency of low cloud.

The monthly and seasonal mean values of total, low-, middle- and high-cloud amounts are presented in Table 1. The seasonal trend shows a mean coverage of $50 \%$ in May, June and July, and a strong increase in August. A large year-to-year difference occurs for June, during which a $10 \mathrm{~d}$ period with diminished cloud amount was responsible for the smaller value in June 1990 compared to June 1991. The large total-cloud amount in August is due to a strong increase in low-cloud amount. The amount of middle cloud was balanced during the summer months and the amount of high cloud decreased slightly in August. For the seasonal mean (June, July, August), nearly half of the total-cloud amount was due to low 
Table 1. Monthly and seasonal mean values of sky covered by low, middle and high clouds and total coverage for the observation periods in 1990 and 1991. The average value (av) is given for both years at ETH Camp. Values are given in percentage. JJA corresponds to June, July and August

\begin{tabular}{|c|c|c|c|c|c|c|c|c|c|c|c|c|c|}
\hline & $\begin{array}{l}\text { May } \\
1991\end{array}$ & 1990 & $\begin{array}{l}\text { June } \\
1991\end{array}$ & av & 1990 & $\begin{array}{l}\text { July } \\
1991\end{array}$ & av & 1990 & $\begin{array}{c}\text { August } \\
1991\end{array}$ & av & 1990 & $\begin{array}{l}\hat{J} \mathcal{J A A} \\
1991\end{array}$ & av \\
\hline Total coverage & 50 & 38 & 60 & 49 & 57 & 46 & 52 & 60 & 79 & 70 & 52 & 62 & 57 \\
\hline Low cloud & 20 & 10 & 22 & 16 & 17 & 17 & 17 & 39 & 49 & 44 & 22 & 29 & 26 \\
\hline Middle cloud & 13 & 15 & 22 & 18 & 19 & 12 & 16 & 15 & 19 & 17 & 16 & 18 & 17 \\
\hline High cloud & 17 & 13 & 16 & 15 & 21 & 17 & 19 & 6 & 11 & 9 & 14 & 15 & 14 \\
\hline
\end{tabular}

cloud and the other half resulted from equal amounts of middle and high cloud. Total-cloud amounts show no significant diurnal cycle and the values are in the range $55-58 \%$. On each level one cloud type is dominant. Half of the low cloud is due to stratus, while $70 \%$ of the middle and high clouds are altocumulus translucidus and cirrus, respectively.

The seasonal frequency distribution of the total-cloud amount is given in Figure 3 . Because of the way that $1 / 8$ and $7 / 8$ are defined, for interpretation purposes $0 / 8$ and $1 / 8$ are considered as one group (clear sky), and $7 / 8$ and $8 / 8$ as another group (overcast sky). Generally, the frequency distribution shows a bimodal feature with large values for clear- and overcast-sky conditions and small values for the partially cloud-covered conditions. The frequency of total-cloudless observations is large in May and June and decreases strongly in July and August. The overcast-sky condition in August $(60 \%)$ is three times more than the cloud-free condition $(20 \%)$. On average, the frequency of clear and overcast sky together applies to nearly three-quarters of all the cases, with $30 \%$ and $42 \%$, respectively.

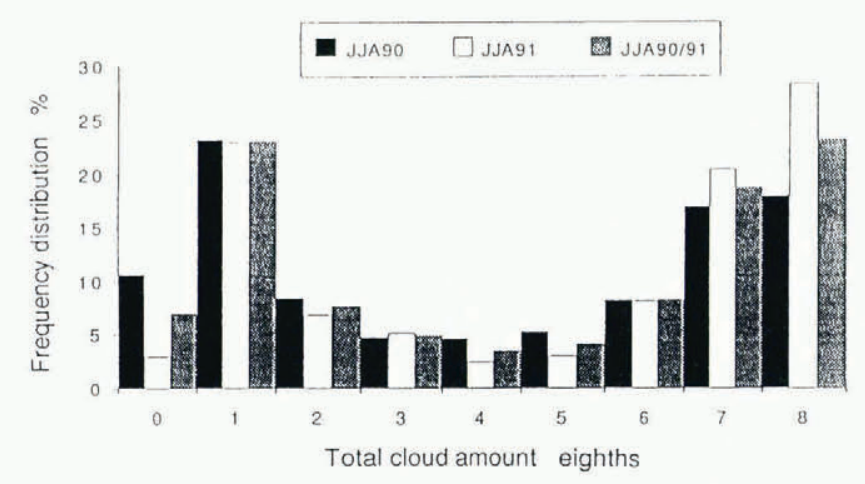

Fig. 3. Seasonal frequency distribution of the tolal-cloud amount for the summer months (June, July, August: J7A) in 1990 and 1991 at ETH Camp.

The distribution of low, middle and high clouds against total-cloud amount shows that high clouds are predominant for $1 / 8$ to $5 / 8$ total-cloud amount conditions. For $6 / 8$ and $7 / 8$, the sky is covered mainly by middle clouds, while most of the $8 / 8$ cases are caused by low clouds. The increase of $8 / 8$ in August is mainly due to low clouds. The frequency of cumulus decreases with increasing low-cloud amount. Stratocumulus shows small values for clear- and overcast-sky conditions, while more than $80 \%$ of $8 / 8$ is due to stratus. Therefore, the main reason for the increase in low-cloud amount in August is the increase in frequency of stratus. This increase in the appearance of stratus affects not only the amount of low cloud but also the total-cloud amount.

\section{Shortwave fluxes}

Based on 3069 half-hourly values, an average difference in direct solar radiation $\left(Q_{\mathrm{m}}-Q\right)$ of $-2.6 \pm 7.2 \mathrm{Wm}^{2}$ was found. The difference is smaller than the uncertainties of the calibration coefficients of the instruments. Therefore, the quality of $Q$ is considered as good and the calculated values will be used in the sections which follow to compare data sets from 1990 and 1991.

The monthly mean diurnal cycles are given in Figure 4. Due to a very sunny period in the second half of June 1990, $Q$ shows extremely high values. Compared with 1990 , no extended period of large $Q$ was found in 1991, but there were two periods, the second half of June and the second half of August, with small values of $Q$ caused by a large total-cloud amount (Table 1). This leads to monthly mean diurnal cycles which show the largest values for July and much smaller values for June and August compared to 1990.

The atmospheric extinction of $Q$ shows seasonal trends. The intensity of $Q$ in 1991 shows highest values for May and lower values for June, August and July. The variation range of the normal incident direct solar radiation is relatively small and amounts to $120 \mathrm{Wm}^{2}$. Ambach (1963) showed a smilar maximum value for measurements in June and July 1959 at Camp IV, and Ambach and Markl (1983) gave a value of $114 \mathrm{~W} \mathrm{~m}^{2}$ at $70^{\circ}$ of zenith angle for Carrefour (Fig. 1). It seems that the intensity of $Q$ under clear-sky conditions shows little scatter on the Greenland ice sheet. The transparency of the atmosphere was investigated with respect to the transmission coefficient for clear-sky conditions. The transmission coefficient calculated for different months varies between 0.814 and 0.836 , by which the year-toyear variation is greater than the variation during the summer months.

Under overcast and partly cloudy conditions, $Q$ is affected by absorption and scattering due to cloud droplets. The attenuation of $Q$ in the presence of clouds is an important factor for the shortwave net radiation at the 

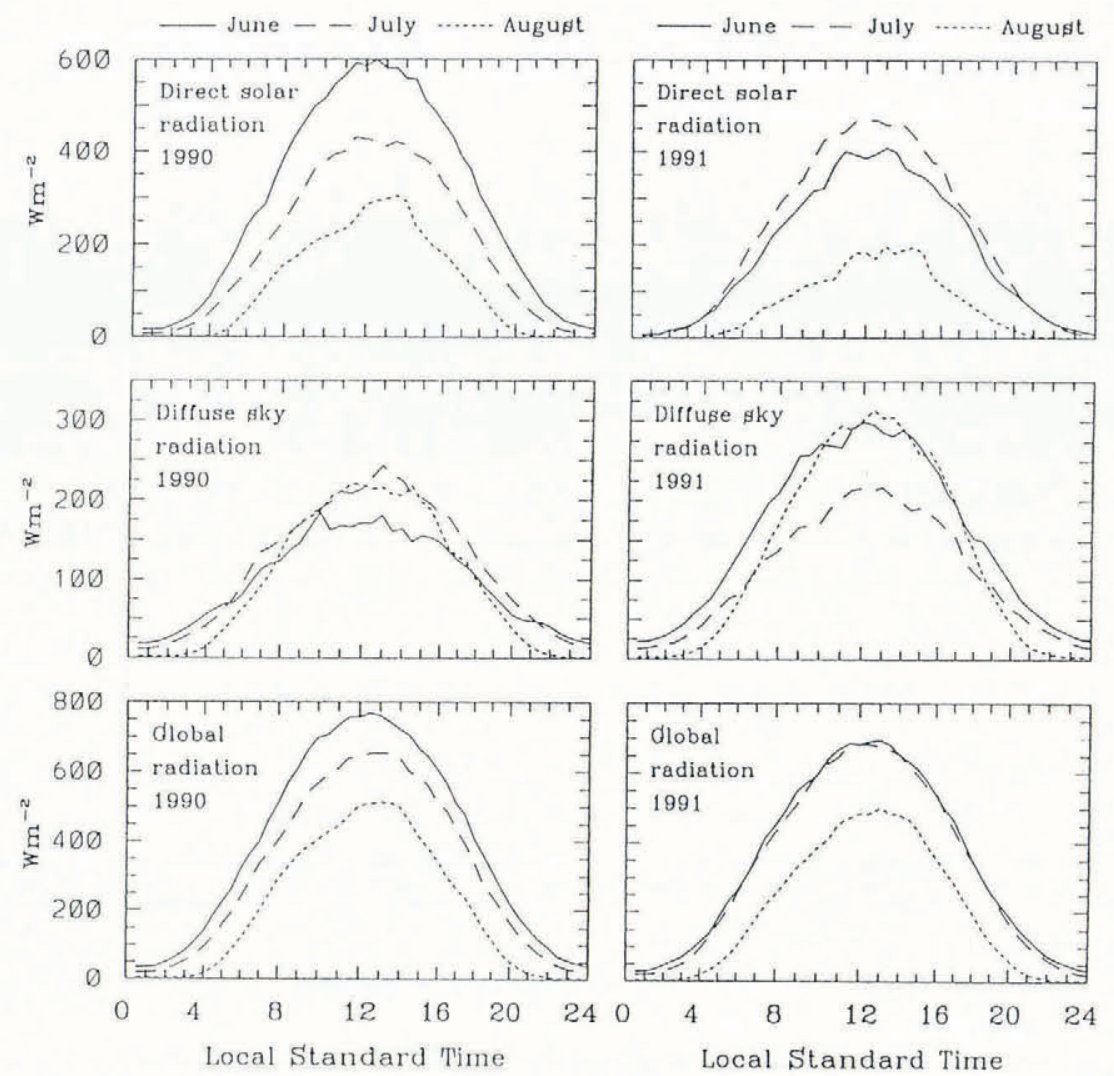

Fig. 4. Mean diurnal cycles of direct solar, diffuse sky and global radiation each for June, fuly and August 1990 and 1991 at ETH Camp.

surface. The daily mean direct solar radiation is analysed with respect to daily mean total-cloud amount and is presented in Figure 5. To eliminate the effect of solar elevation, $Q$ was normalized by the extraterrestrial solar radiation $(I)$. The daily direct solar radiation is about $70 \%$ of daily extraterrestrial solar radiation under clear-sky conditions and decreases slightly to a total-cloud amount of $3 / 8$. For up to $3 / 8$ total-cloud amount, the frequency of high clouds is large, while the frequency of middle and low clouds increases strongly from $5 / 8$ to $8 / 8$ of total-cloud amount. This leads to large transmissivity under less-covered sky and to low transmissivity for larger total-cloud amounts.
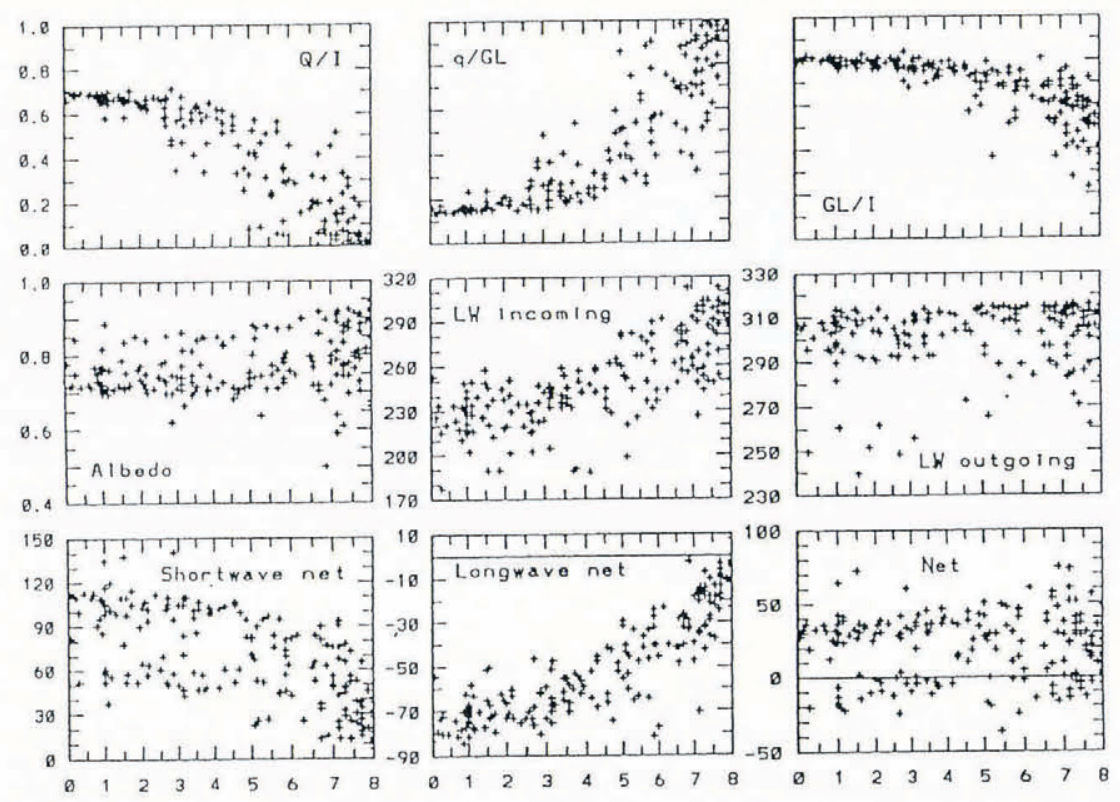

Total cloud amount eighths

Fig. 5. Relationship between daily total-cloud amount and daily mean values of the radiative fluxes for fune-August 1990 and May-August 1991 at ETH Camp. Units: $W^{-2}$ and ratio for albedo, $Q / I, q / G L$ and GL/I. 
The monthly mean diurnal cycles of diffuse sky radiation in 1990 show the largest amplitude for July (Fig. 4). The mean diurnal amplitude for June shows smaller values for high solar elevations compared to August. This fact results in similar monthly mean values as shown in Table 2. Under clear-sky conditions, $q$ depends mainly on the scattering of aerosols and molecules, the absorption in the atmosphere and on the albedo of the surface. Observations in 1991 show a strong decrease in diffuse sky radiation with increasing zenith angle and a seasonal dependency. The values of $q$ decrease from May to July and increase slightly in August. This difference is probably caused by the atmospheric and surface conditions as mentioned earlier. The precipitable water vapour in the atmosphere $(W)$ is small and increases from $2.9 \mathrm{~kg} \mathrm{~m}^{-2}$ in May to $6.0 \mathrm{~kg} \mathrm{~m}^{-2}$ in August. Holmgren (1971) gave values between 3.0 and $7.0 \mathrm{~kg} \mathrm{~m}^{-2}$ for the same period at Ice Cap Station on Devon Island in the Canadian Arctic. Because of this variation of $W$, the variation of $q$ under clear-sky conditions due to water vapour is considered to be small. The attenuating effect of aerosols can be expressed by Ångström's turbidity coefficient. To characterize the turbidity of the air at the study site, measurements performed by Ambach (1963) in June and July 1959 are taken into account. Angström's turbidity coefficients, adjusted to station height, show daily mean values between 0.010 and 0.027. After Liljequist (1956) and Holmgren (1971), this variation of the turbidity coefficient corresponds to a variation in $q$ of $11 \mathrm{~W} \mathrm{~m}^{2}$ at $50^{\circ}$ zenith angle. At the present study site, the variation of $q$ at $50^{\circ}$ zenith angle is three times larger. It seems that the surface albedo and the diurnal amplitude of global radiation are mainly responsible for the variation of $q$ under clear-sky conditions.

Under overcast-sky and partly cloud-covered sky conditions, $q$ is contributed to by reflections and diffuse refraction at cloud droplets. The ratio of daily mean diffuse-sky radiation and global radiation $(q / G L)$ is given in Figure 5. The amount of $q$ is steady from $0 / 8$ to $3 / 8$ total-cloud amount, increases up to $8 / 8$ and shows a maximum at $7 / 8$. The large variation of $q$ between $7 / 8$ and $8 / 8$ is mainly due to the season, while the strong scattering of points between $3 / 8$ and $7 / 8$ depends on cloud types and on albedo of the lower side of the clouds. The relation $q / G L$ is 0.5 at a total-cloud amount of about $2 / 3$.

During the summer months, global radiation is composed of $60 \%$ direct solar and $40 \%$ diffuse-sky radiation. Direct solar and diffuse-sky radiation show large variations (monthly mean values) from year to year, while global and shortwave reflected radiation vary less (Table 2). The decrease in $Q$ due to increasing cloud amount is partly compensated for by $q$. The percentage of compensation increases not only because of larger totalcloud amount but also due to high surface albedo and changing cloud distributions. The frequency of low clouds increases with increasing total-cloud amount, of which the stratus-cloud type is the most dominant. The effect of daily total-cloud amount on the daily ratio $G L / I$ is given in Figure 5. The effect of latitude and declination is eliminated in $G L / I$. The increase of scattering for the increasing total-cloud amount depends on cloud types and the daily course of cloudiness. That means, for instance, a strong increase of total-cloud amount in the early afternoon, which leads to an underestimation of $G L$ and $G L / I$ compared to total-cloud amount. The influence of total-cloud amount and cloud types leads to a variation in $G L / I$ from 61 to $74 \%$, with an average of about $70 \%$ for the summer months (Table 2). Thus, for parameterization of $G L$, it is advisable to take cloud types (especially for low clouds) into account if high-quality cloud data are available. The seasonal global radiation is $4 \%$ smaller in 1991 than in 1990 and the lack of $Q$ in 1991 is almost compensated for by $q$.

Table 2. Radiative fluxes observed at ETH Camp (69 $34^{\prime} \mathrm{N}, 49^{\circ} 17^{\prime} \mathrm{W}, 1155 \mathrm{~m}$ a.s.l.) on the Greenland ice sheet. I: extraterrestrial solar radiation, $\alpha(g)$ : albedo at ground level, $\alpha(l)$ : albedo from the tower. The number in brackets represents the number of days when the observation was made. The average of 1990 and 1991 values is given in column (av). $77 \mathrm{~A}$ corresponds to June, July and August. Unit: $\mathrm{Wm}^{2}$

\begin{tabular}{|c|c|c|c|c|c|c|c|c|c|c|c|c|c|}
\hline & \multicolumn{2}{|c|}{ May } & \multicolumn{2}{|c|}{ June } & \multicolumn{3}{|c|}{ July } & \multicolumn{3}{|c|}{ August } & \multicolumn{3}{|c|}{$J \overline{J A}$} \\
\hline & $\begin{array}{c}1991 \\
(21)\end{array}$ & $\begin{array}{c}1990 \\
(22)\end{array}$ & $\begin{array}{l}1991 \\
(28)\end{array}$ & av & $\begin{array}{c}1990 \\
(28)\end{array}$ & $\begin{array}{l}1991 \\
(31)\end{array}$ & av & $\begin{array}{l}1990 \\
(28)\end{array}$ & $\begin{array}{r}1991 \\
(27)\end{array}$ & av & $\begin{array}{c}1990 \\
(78)\end{array}$ & $\begin{array}{c}1991 \\
(86)\end{array}$ & av \\
\hline$I$ & 408 & & & 486 & & & 450 & & & 327 & & & 421 \\
\hline$Q$ & 205 & 285 & 183 & 234 & 195 & 214 & 204 & 106 & 68 & 87 & 195 & 155 & 175 \\
\hline$q$ & 121 & 96 & 154 & 125 & 115 & 108 & 112 & 95 & 129 & 112 & 102 & 130 & 116 \\
\hline$G L$ & 326 & 381 & 337 & 359 & 310 & 322 & 316 & 201 & 197 & 199 & 297 & 285 & 291 \\
\hline$\alpha G L(\mathrm{~g})$ & -280 & -282 & -259 & -271 & -214 & -239 & -227 & -151 & -166 & -158 & -215 & -221 & -218 \\
\hline$\alpha g l(t)$ & -277 & -282 & -258 & -270 & -215 & -237 & -226 & -145 & -161 & -153 & -214 & -219 & -219 \\
\hline$\alpha(g)$ & 0.859 & 0.740 & 0.769 & 0.755 & 0.690 & 0.742 & 0.718 & 0.751 & 0.843 & 0.794 & 0.724 & 0.775 & 0.749 \\
\hline$\alpha(t)$ & 0.846 & 0.740 & 0.766 & 0.752 & 0.694 & 0.736 & 0.715 & 0.721 & 0.817 & 0.769 & 0.721 & 0.768 & 0.742 \\
\hline$L_{i}$ & 219 & 239 & 260 & 248 & 257 & 256 & 257 & 258 & 268 & 263 & 250 & 261 & 256 \\
\hline$L_{\mathrm{o}}$ & -266 & -304 & -307 & -306 & -308 & -310 & -309 & -302 & -297 & -300 & -305 & -304 & -305 \\
\hline$S W_{\text {net }}$ & 46 & 99 & 78 & 88 & 96 & 83 & 89 & 50 & 31 & 41 & 82 & 64 & 73 \\
\hline$L W_{\text {net }}$ & -47 & -69 & -47 & -58 & -51 & -54 & -52 & -44 & -29 & -37 & -55 & -43 & -49 \\
\hline$N R_{\mathrm{c}}$ & -1 & 30 & 31 & 30 & 45 & 29 & 37 & 6 & 2 & 4 & 27 & 21 & 24 \\
\hline$G L / I$ & 0.799 & 0.784 & 0.693 & 0.739 & 0.689 & 0.716 & 0.702 & 0.615 & 0.602 & 0.609 & 0.706 & 0.677 & 0.691 \\
\hline
\end{tabular}


Shortwave reflected radiation depends on $G L$ and the reflectivity (albedo) of the surface. At the present site, $\alpha G L$ was measured at ground level (standard height) and from the tower $(27 \mathrm{~m}$ height $)$ in order to represent a larger observation area. The influences of the aluminium tower and the camp on measurements are minimal $(<0.5 \%)$ and will be neglected. Albedo is composed of a diffuse and a specular component. It is influenced mainly by the properties of the surface, the solar elevation and the cloud conditions, and shows a spectral dependency for snow and ice (Warren, 1982). During the field seasons, surface conditions changed from wet snow to bare ice and fresh snow in 1990 and from dry snow to wet snow, saturated snow, slush and fresh snow in 1991. Due to these surface properties, the variation of the daily mean albedo ranged from 0.50 to 0.89 in 1990 and from 0.66 to 0.92 in 1991, respectively. The mean seasonal albedo is centred about 0.75 (Table 2). The monthly diurnal cycles of albedo show small ranges $(2-7 \%)$ with a slight increase from morning to afternoon (Fig. 6). Because of small amounts of shortwave radiative fluxes and the lower accuracy of global radiation measurements for a large zenith angle $(Z)$, the diurnal cycle of albedo is only considered for $Z<70^{\circ}$. During both years, daily mean albedo at ground level and from the tower show similar values for June and July. For August 1990-91 and May 1991 , daily mean albedo values from the tower are up to $6 \%$ lower. This indicates the influence of surface topography (sastruga) and solar elevation on shortwave reflected radiation from areas with different sizes. For remote-sensing applications, shortwave reflected radiation measurements from the high tower for pre- and postmelt seasons are more meaningful in order to prevent the influence of the various factors mentioned above. Because of the high albedo, shortwave reflected radiation is greater in 1991, although global radiation is smaller.

Under clear-sky conditions, the features of the diurnal cycle show a wide variation. Five diurnal cycles for clear- sky conditions in 1991 are shown in Figure 7 . The range is generally very small (3-8\%). Except for 14 May (dry snow), measurements were made above wet snow, the saturated snow layer or slush. To eliminate uncertainties of the up-facing pyranometer under a lower solar elevation, the diurnal cycle of albedo was calculated with respect to the sum of $Q_{\mathrm{m}}$ and $q$ using the 1991 data

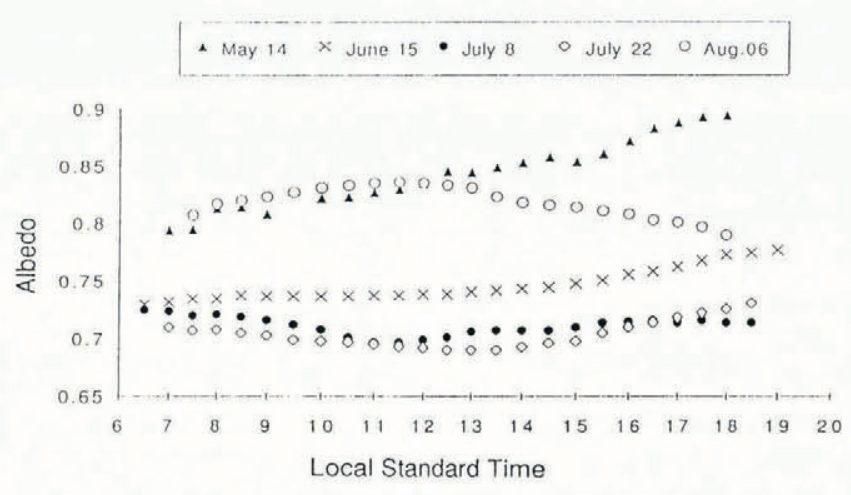

Fig. 7. Diurnal cycles of albedo at ground level under clear-sky conditions for different days in 1991. Only values of zenith angle less than $70^{\circ}$ are considered.

(Fig. 8). The nature of the curves is similar. Therefore, no influence of $G L$ measured by pyranometer on albedo can be demonstrated conclusively. In the same figure, the diurnal cycle of albedo from the tower is given. During the day, albedo at the tower is a little smaller or equal to the albedo at ground level but it increases strongly after $1630 \mathrm{~h} \mathrm{LST}$. This higher reflectivity in the afternoon for a large area under clear-sky conditions indicates a slight increase in actual global radiation received on the slope of the surface, which falls gently to the west.

Two main groups must be distinguished for the effect of total-cloud amount on daily mean albedo (Fig. 5): (1)
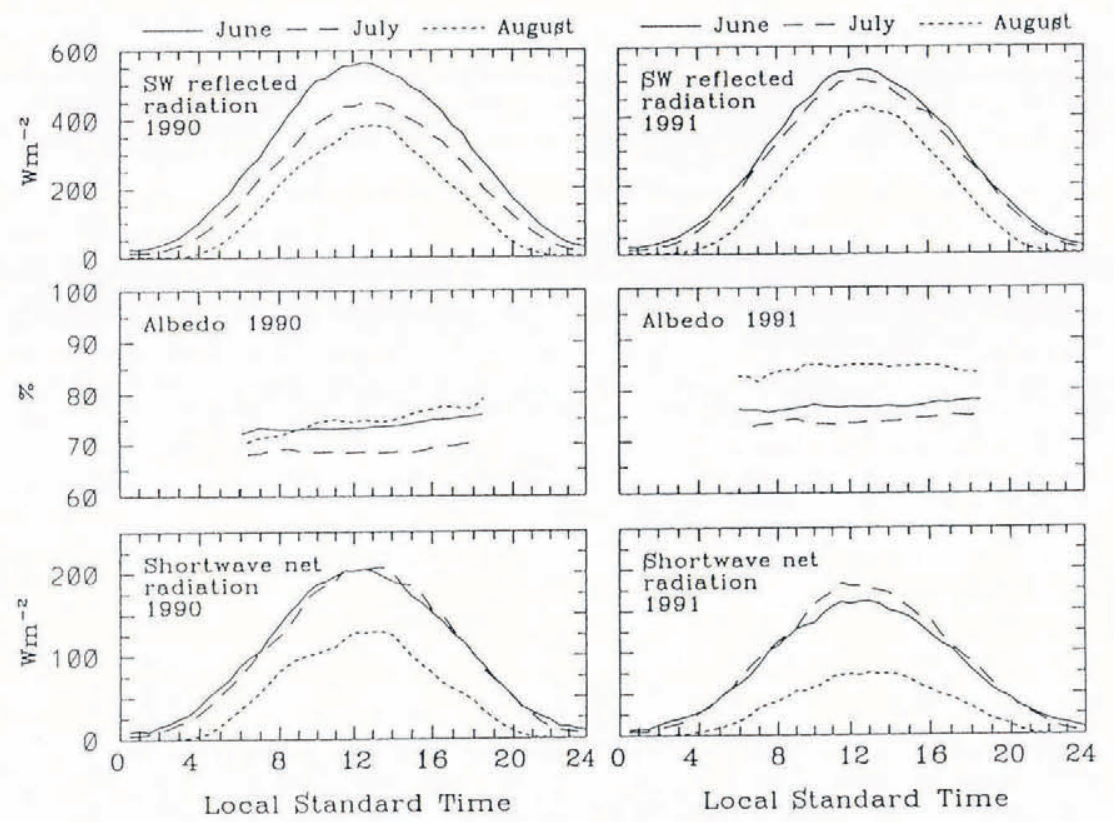

Fig. 6. Mean diurnal cycles of shortwave (SW) reflected radiation, albedo at ground level and shortwave net radiation, each for June, July and August 1990 and 1991 at ETH Camp. 


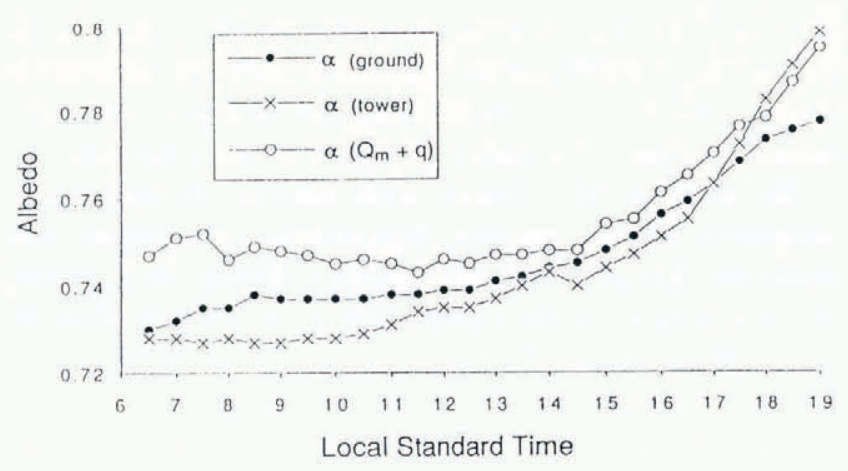

Fig. 8. Diurnal cycles of albedo at ground level, from the tower and at ground level (calculated as the sum of $Q_{\mathrm{m}}$ and q) under clear-sky conditions for 15 June 1991. Notice the different scales of the axis than given in Figure 7.

dry snow and (2) wet snow. The first group shows a daily mean of 0.85 up to a total-cloud amount of $5 / 8$ and increases slightly to about 0.91 for $8 / 8$. The second group shows values between 0.70 and 0.77 up to $5 / 8$ and an increase of $5 \%$ up to $8 / 8$ total-cloud amount. Daily mean values of albedo of less than 0.65 are obtained above ice surfaces and show no dependency on total-cloud amount. The higher reflectivity of the snow cover under overcast conditions in comparison with clear-sky conditions is mainly due to alteration of the spectral intensity of $G L$ by increasing amounts of water droplets and water vapour.

The monthly mean diurnal cycles of shortwave net radiation $\left(S W_{\text {net }}\right)$ for June and July 1990 show similar amplitudes which indicates that the much larger $G L$ in
June is compensated for by the lower albedo in July (Fig. $6)$. In 1991 , the seasonal mean reaches $78 \%$ of the amount from 1990 which is due to smaller $G L$ and higher albedo in 1991. The effect of total-cloud amount on daily shortwave net radiation is shown in Figure 5. As for the albedo, two groups are distinguished for dry- and wetsnow conditions. For dry snow, $S W_{\text {net }}$ is around $55 \mathrm{~W} \mathrm{~m}^{-2}$ up to $5 / 8$, which corresponds to half the amount found for wet-snow conditions. From $5 / 8$ to $8 / 8, S W_{\text {net }}$ decreases by $50 \%$. For wet snow, $S W_{\text {net }}$ decreases slightly from $0 / 8$ to $4 / 8$ and drops by about $50 \%$ to $8 / 8$ total-cloud amount.

\section{Longwave fluxes}

The longwave incoming radiation derived from instruments was compared with the values calculated using LOWTRAN7, a band model (Kneizys and others, 1988), given in Konzelmann and others (1994). For clear-sky conditions, measurements are on average larger than LOWTRAN7 calculations by $10 \pm 4 \mathrm{Wm}^{2}$. However, differences between measurements and calculations are to be viewed with caution because of the uncertainties of both methods. Calculations with LOWTRAN7 are useful for checking instantaneous measurements of $L_{\mathrm{i}}$ under clear-sky conditions. Especially due to the frequent cloud covers and complexities caused by them, continuous measurements cannot be replaced by computations.

$L_{\mathrm{i}}$ shows monthly mean diurnal cycles with small variations (Fig. 9). Different features in July and August 1990 can be explained by the varying frequency of occurrence of low, middle and high clouds, and altering diurnal cycles of cloudiness. In 1991, values for June show
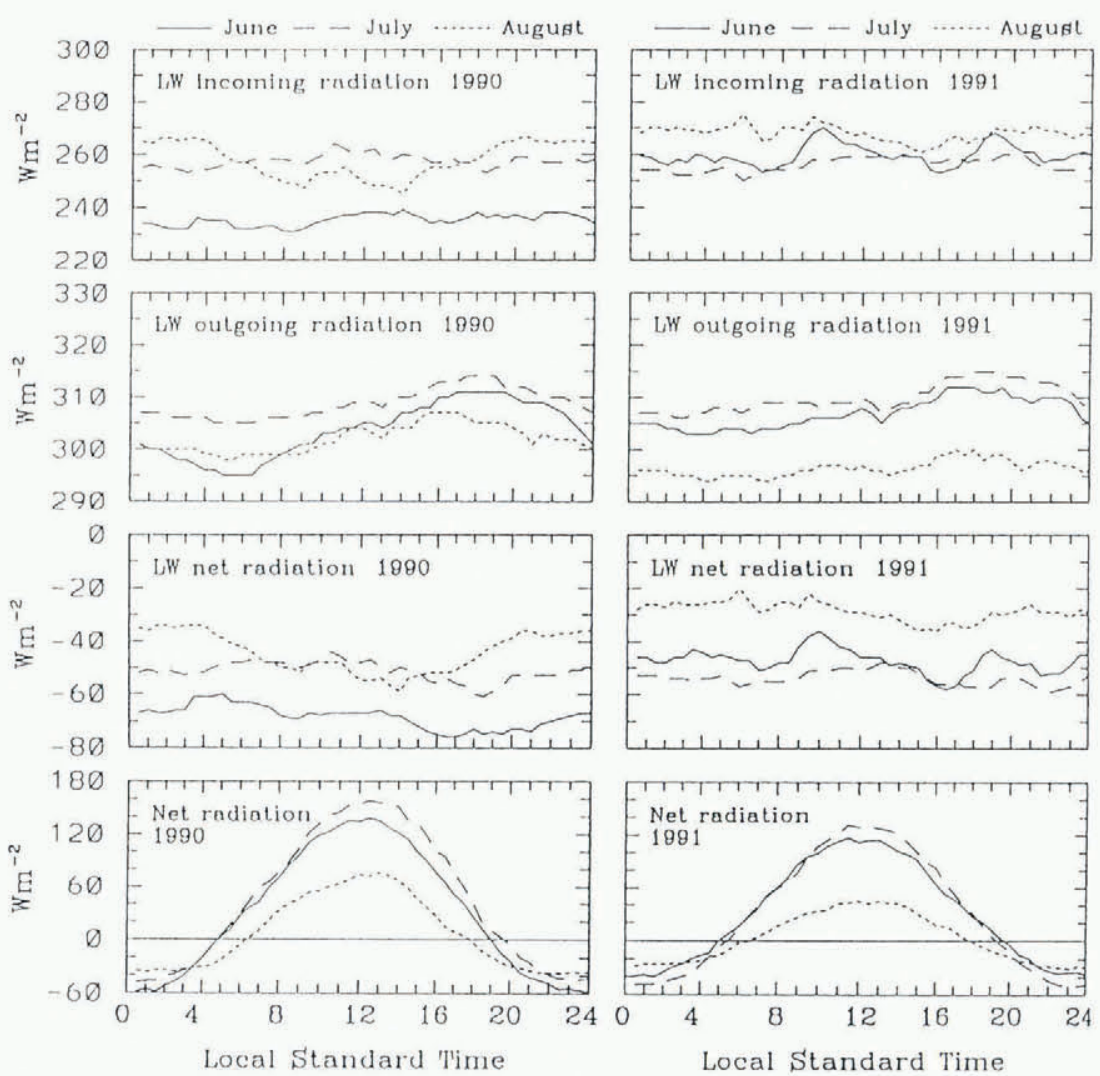

Fig. 9. Mean diurnal cycles of longwave ( $L W$ ) incoming radiation, longwave outgoing radiation, longwave net radiation and net radiation, each for June, July and August 1990 and 1991 at ETH Camp. 
a larger amplitude and two peaks, one in the morning and the other in the late afternoon. This is probably due to a larger cloud amount. The monthly mean values for 1991 are more balanced compared to 1990 and the seasonal mean is 4\% larger than in 1990 (Table 2). The monthly total-cloud amount for the summer months (Table 1) is in good agreement with the monthly longwave incoming radiation but $L_{\mathrm{i}}$ does not always correspond to the monthly mean diurnal cycles as suggested by the screen-level temperature Ohmura and others, 1992b, p. 19). It seems that $L_{\mathrm{i}}$ has a better correlation with cloud conditions than with air temperature. The variations in daily cloud conditions (amount and type) should be taken into account by calculating $L_{\mathrm{i}}$ with numerical models. For a total-cloud amount of up to $3 / 8$, the $L_{\mathrm{i}}$ is centred around $230 \mathrm{~W} \mathrm{~m}^{-2}$ (Fig. 5). From $3 / 8$ to overcast conditions, $L_{\mathrm{i}}$ increases strongly and shows values close to $300 \mathrm{~W} \mathrm{~m}^{2}$ at $8 / 8$ total-cloud amount.

Snow and ice surfaces in a melting condition were predominant at the study site. The steady temperature of $0^{\circ} \mathrm{C}$ offered an opportunity to check the measurements, as it is done for absolute calibration over an ice-water surface. Longwave outgoing radiation shows generally very smooth cycles with small amplitudes. The mean diurnal cycle for 1990 (Fig. 9) shows the largest amplitude $\left(15 \mathrm{~W} \mathrm{~m}^{2}\right)$ with a minimum at $0600 \mathrm{~h} \mathrm{LST}$ and a maximum at $1800 \mathrm{~h} \mathrm{LST}$. These correspond to a time lag of $1 \mathrm{~h}$ compared to the mean diurnal variation of air temperature at screen level, with air temperature ahead of the phase. In June 1991, the mean diurnal cycle is similar to July and more dampened compared to June 1990, because of the smaller amplitude of the air temperature. The month-to-month variation is larger in 1991 than in 1990 but the seasonal mean is the same (Table 2). Except for the pre-melt season, there is no conclusive evidence that cloud conditions influence $L_{0}$ (Fig. 5).

Based on half-hourly values for the period MayAugust 1991, the surface temperature was calculated from $L_{\mathrm{o}}$. This period was chosen because of the larger range of values and more accurate screen-level air-temperature measurements due to ventilation. The difference between screen-level air temperature and thermal radiation from the surface varies for individual months. May shows the largest temperature difference $\left(2.89 \pm 1.47^{\circ} \mathrm{C}\right)$ which is due to a strong increase in air temperature in the second half of the month and to the cooling of the snow surface by the underlying cold snow layers. June and August show much smaller temperature differences, $1.44 \pm 1.09$ and $1.44 \pm 1.08^{\circ} \mathrm{C}$, respectively. For both months, the monthly mean air temperature is below $0^{\circ} \mathrm{C}$ and the surface (snow or slush) is melting. The significantly larger value for July $\left(1.77 \pm 1.03^{\circ} \mathrm{C}\right)$ is caused by a much higher air temperature. Daily mean longwave outgoing radiation can be parameterized by using the screen-level air temperature. Based on daily mean values from Summit (Fig. 1) and ETH Camp, the relationship between $L_{\mathrm{o}}$ and screen-level temperature $\left(T_{\mathrm{a}}\right)$ was calculated. The linear regression shows a correlation coefficient of 0.983 . For $T_{\mathrm{a}}<1.7^{\circ} \mathrm{C}, L_{\mathrm{o}}$ can be expressed as

$$
L_{\mathrm{o}}=4.5667 T_{\mathrm{a}}+308.14
$$

by which $L_{\mathrm{o}}$ is given in $\mathrm{Wm}^{-2}$ and $T_{\mathrm{a}}$ in ${ }^{\circ} \mathrm{C}$. A value of
$316 \mathrm{~W} \mathrm{~m}^{-2}$ for $L_{\mathrm{o}}$ (melting surface) can be expected for $T_{\mathrm{a}}>1.7^{\circ} \mathrm{C}$. Observations from the pre- to post-melt seasons indicate that the temperature gradient near the surface increases for higher altitudes at the same time.

Because of the lower atmospheric temperature compared to the surface temperature, longwave net radiation $\left(L W_{\text {net }}\right)$ is mostly negative during the summer months, indicating the energy loss at the surface. Due to the steady values of $L_{0}$ during the melt season, $L W_{\text {net }}$ is strongly characterized by $L_{\mathrm{i}}$. Therefore, $L W_{\text {net }}$ depends mainly on total-cloud amount and cloud types. During the pre-melt season $L_{\mathrm{i}}$ is smaller compared to the melting season, while $L_{0}$ (due to the low snow temperature) is much smaller. This leads to an amount of $L W_{\text {net }}$ which is larger compared to the melting season. The largest amounts of $L W_{\text {net }}$ can be expected during the post-melt season due to greater $L_{\mathrm{i}}$ (cloud conditions) and minimal $L_{\mathrm{o}}$ (temperature at the surface $<0^{\circ} \mathrm{C}$ ).

The mean diurnal cycle of $L W_{\text {net }}$ for June 1990 shows a decrease in the late afternoon because of $L_{\mathrm{o}}$ (Fig. 9). The monthly mean longwave net radiation increases from June to August because of increasing total-cloud amount and a smaller amount of $L_{\mathrm{o}}$ in August (Table 2). In 1991, the features of monthly mean diurnal cycles are similar to those of $L_{\mathrm{i}}$. Because of the smaller $L_{\mathrm{o}}$ in August, the level of the diurnal cycle of $L W_{\text {net }}$ is larger. July shows the smallest monthly mean value, while the value for August is much larger. This is caused by the higher total-cloud amount and the lower surface temperature in August. For a total-cloud amount of up to $3 / 8$, the daily mean longwave net radiation is centred around $-70 \mathrm{~W} \mathrm{~m}^{-2}$ (Fig. 5 ) and increases strongly for overcast conditions $\left(-10 \mathrm{~W} \mathrm{~m}^{-2}\right)$.

\section{Radiation balance}

The possible underestimation of net radiation, mentioned earlier, leads to a large relative error at locations with high surface reflectivities. During the main melt period (June, July) at ETH Camp, the differences between net radiation derived by the two different methods, in terms of melt rate, corresponds to about $350 \mathrm{~mm}$ w.e. This amount of difference cannot be ignored, as it is equivalent to the mean annual accumulation of Greenland (Ohmura and Reeh, 1991).

At the present site near the mean ELA, an energy gain at the surface due to radiative fluxes can be expected from late May to mid-August, while during the pre-melt season (in May) the amount of net radiation is centred around zero $\mathrm{W} \mathrm{m}^{-2}$. The monthly mean diurnal cycles for 1990 (Fig. 9) show the highest values for July during the daytime and the highest values for August during the "night-time". These features indicate that net radiation depends mainly on declination (global radiation), reflectivity of the surface and cloud conditions. The monthly mean net radiation increases from June to July by $50 \%$ and decreases strongly in August but it retains a positive value. In July 1991, the largest net radiation values are found during the daytime and the smallest values are found during the "night", while the situation for August is reversed. The monthly mean net radiation is below zero $\mathrm{W} \mathrm{m}^{-2}$ in May (Table 2), peaks at a similar amount for June and July, and decreases to a value close to 
zero $\mathrm{W} \mathrm{m}^{-2}$ in August. Net radiation in June 1990 and June 1991 are similar. This indicates that the smaller amount of $S W_{\text {net }}$ in 1991 (because of a lack of $G L$ ) is compensated for by the increase in total-cloud amount. The smaller amount of net radiation in July 1991 is mainly due to the higher albedo in 1991. In August 1991, the smaller $S W_{\text {net }}$ (because of the higher albedo) is almost compensated for by the larger cloud amount and lower surface temperature. The seasonal mean net radiation is more than $20 \%$ smaller in 1991 than in 1990 and shows an absolute difference of $6 \mathrm{~W} \mathrm{~m}^{-2}$. The larger value for 1990 can be explained by the greater amount of $G L$ and lower albedo in 1990, which could not be completely compensated for by the greater cloud amount in 1991.

The effect of total-cloud amount on daily mean net radiation is shown in Figure 5. To eliminate the effect of declination and albedo, net radiation is analysed separately for May (dry snow), June-July (wet snow) and August (dry snow). The decrease of $S W_{\text {net }}$ due to increasing cloud amount is compensated for by an increase in $L W_{\text {net }}$ for dry-snow conditions in May. The mean albedo for May is high $(85 \%)$ and the distribution of low, middle and high cloud amounts is uniform (Table 1). In June-July, daily mean albedo shows values between 50 and $91 \%$ with an average of $74 \%$. Daily net radiation increases very slightly but it is not significant, at a rate of $<0.8 \mathrm{~W} \mathrm{~m}^{-2}$ with a $1 / 8$ increase of cloud amount. This indicates that $L W_{\text {net }}$ is able to compensate for the decrease of $S W_{\text {net }}$ due to increasing cloud amount. For dry-snow conditions in August, daily mean albedo is mostly between 75 and $90 \%$ with an average of $84 \%$. Daily net radiation shows a weak trend toward increase from clear-sky to overcast-sky conditions. The difference between May and August could be due to different cloud schemes which show much more low cloud of the stratus type in August than in May. For dry-snow conditions at Carrefour, Ambach (1974) showed an increase in net radiation of about $23 \mathrm{~W} \mathrm{~m}^{-2}$ from $0 / 8$ to $8 / 8$, while at ETH Camp the values of net radiation are more or less steady. At Camp IV, Ambach (1977) observed an increase in net radiation of about $27 \mathrm{~W} \mathrm{~m}^{-2}$ from clear-sky to overcast conditions for days with an albedo $>70 \%$. This relation, in which net radiation increases with increasing cloud amount for an albedo $>75 \%$ (Ambach, 1974), could not be found in the same order of magnitude at the present study site. This discrepancy could be caused by a possible underestimation of net radiation (see above) measured by using the unshaded method or by different cloud schemes (types) at the various locations.

\section{Comparison with other locations}

To put the measurements of radiative fluxes at ETH Camp in a larger perspective, a comparison with results from other locations (Fig. 1) on the Greenland ice sheet is made. As a contribution to the Greenland Icecore Project (GRIP), a European Scientific Foundation programme with eight nations collaborating to drill through the central Greenland ice sheet, radiative-flux measurements and synoptic observations were made at Summit (personal communication from A. Abe-Ouchi). The earlier works are converted to WRR (Fröhlich and London,
1986). Since Ambach (1963, 1977), at Camp IV, and Ambach and Markl (1983), at Carrefour, used a value for Stefan-Boltzmann's constant that was $1.25 \%$ larger than the currently accepted value $\left(=5.67 \times 10^{-8} \mathrm{~W} \mathrm{~m}^{-2} \mathrm{~K}^{-4}\right)$, their longwave radiative-flux measurements were divided by a factor of 1.0125 . In addition, it must be mentioned that ETH Camp was the only location where longwave incoming, longwave net and net radiation were obtained with shaded radiometers. Therefore, a systematic difference due to the different methods of measurement cannot be excluded.

Cloud observations from other locations on the Greenland ice sheet are very rare. At Summit, the totalcloud amount in June 1991 was a little larger than at ETH Camp but the values are based on only three observations a day. E.A. C. Henneken (personal communication) has given a value of sky covered by clouds of $49 \%$ for July 1991 at Gimex-FUA, an ice-sheet station ( $1520 \mathrm{ma}$ a.s.l.), which is slightly larger than at ETH Camp. At Gimex-IMAU (Oerlemans and Vugts, 1993), a station close to the ice margin, the trend for June and July 1991 is similar but the amount is a little less than given in this study. The observations at various locations show a slight increase in total-cloud cover from coast to summit for June 1991 (Gimex-IMAU: 58\%; ETH Camp: 60\%; Summit: $65 \%$ ) and the same trend for July 1991 (GimexIMAU: $41 \%$; ETH Camp: 46\%; Gimex-FUA: 50\%). The results from various locations are close to each other and the uncertainty is large because of a small data base and different observers, observing intervals, locations and time-scales. Therefore, no definite conclusion about the geographical distribution of the total-cloud amount on the Greenland ice sheet can be provided but the observations are helpful to interpret radiative fluxes.

Global radiation is the most commonly measured component of the radiation balance. $G L / I$ and the ratio of minimum and maximal $G L$ are considered for comparing daily mean values for various study sites (Fig. 1; Table 3). Values are given for June and July but they are based on measurements for different years and numbers of days. The ratio $G L_{\min } / G L_{\max }$ increases with increasing elevation and shows a much higher value at Summit (3230 ma.s.l.) than at Gimex-IMAU at the ice margin. The range of variation of $G L / I$ is small at Summit and increases with decreasing elevation, while the averages of the ratio $G L / I$ show no significant trend. This feature can be explained by the existence of low clouds (especially of the stratus type) close to the ice margin.

Generally, $G L$ increases from $60^{\circ}$ to $70^{\circ} \mathrm{N}$, remains steady further to the north and increases from the ice margin to the ice sheet. In June, GL at the ice margin increases from the south to the Arctic Circle from about $200 \mathrm{Wm}^{-2}$ at Nordbogletscher to about $260 \mathrm{~W} \mathrm{~m}^{-2}$ at Qamanârssûp (Braithwaite and Olesen, 1985) and at Gimex-IMAU. Around $70^{\circ} \mathrm{N}$, the amount of $G L$ is 330 $360 \mathrm{~W} \mathrm{~m}^{-2}$. The year-to-year variation for June was large at ETH Camp with $381 \mathrm{~W} \mathrm{~m}^{-2}$ in 1990 and $337 \mathrm{~W} \mathrm{~m}^{-2}$ in 1991. The value for 1991 accords with simultaneous measurements at Summit which show $357 \mathrm{~W} \mathrm{~m}^{-2}$. The value obtained at Carrefour $\left(362 \mathrm{~W} \mathrm{~m}^{-2}\right.$; $1850 \mathrm{ma.s.l}$.) appears reasonable considering the variability of $G L$ observed in June at ETH Camp. At the Gimex transect 
Table 3. Comparison of the ratio global to extraterrestrial solar radiation $G L / I$ (range and average) and the ratio of minimum and maximal $G L$ for various study sites on the Greenland ice sheet referred to in the text. Data are based on daily mean values for fune and july. The number in brackets represents the number of days taken into account

\begin{tabular}{lcccc}
\hline Location & Month & $\begin{array}{c}G L / I \\
\text { Range }\end{array}$ & $\begin{array}{c}\text { GL/I } \\
\text { Average }\end{array}$ & GL \\
& & & & \\
\hline Summit (GRIP) & June (17) & $0.61-0.80$ & 0.71 & 0.76 \\
Site II & July (26) & $0.52-0.90$ & 0.69 & 0.54 \\
Ciarrefour & June, July (57) & $0.57-0.89$ & 0.76 & 0.61 \\
Gimex-FUA & July (27) & $0.43-0.84$ & 0.72 & 0.47 \\
ETH Camp & June, July (109) & $0.28-0.84$ & 0.72 & 0.28 \\
Camp IV & June, July (61) & $0.29-0.80$ & 0.64 & 0.38 \\
Gimex-IMAU & June, July (52) & $0.19-0.73$ & 0.58 & 0.25 \\
& & & &
\end{tabular}

(around $67^{\circ} \mathrm{N}$ ) $G L$ is $283 \mathrm{~W} \mathrm{~m}^{-2}$ in July at the ice margin and $320 \mathrm{~W} \mathrm{~m}^{-2}$ at the ELA. This value is the same as the observation at ETH Camp in the same year. Measurements at Camp IV show smaller values of $G L$ for June and July compared to the very close ETH Camp site, where total-cloud amount for June is smaller in 1990 and greater in 1991. In July, total-cloud amount is smaller in both years at ETH Camp but GL is much larger at ETH Camp $\left(316 \mathrm{~W} \mathrm{~m}^{-2}\right)$ than at Camp IV $\left(279 \mathrm{~W} \mathrm{~m}^{-2}\right)$. Comparing the results from various locations close to the ELA, the amount of GL observed at Camp IV seems to be at the lower limit. Therefore, an amount between 320 and $360 \mathrm{~W} \mathrm{~m}^{-2}$ can be expected for June and July in the accumulation area between $67^{\circ}$ and $72^{\circ} \mathrm{N}$. Further north, $G L$ decreases slightly in July to about $320 \mathrm{~W} \mathrm{~m}^{-2}$ considering site II (Diamond and Gerdel, 1958) and Kronprins Christian Land (KCL) in eastern north Greenland (Konzelmann and Braithwaite, 1995). Measurements of $G L$ in August are fairly rare. The year-toyear variation at ETH Camp is slight and the amount of global radiation (about $200 \mathrm{Wm}^{-2}$ ) is similar to the observations at the Ice Cap Station on Devon Island.

Albedo values for various study sites are given in Table 4. For June and July, the albedo seems steady at the lower ablation area (Gimex-IMAU; $341 \mathrm{~m}$ a.s.l.), while the albedo decreases strongly in the upper ablation area (Camp IV; $1004 \mathrm{~m}$ a.s.l.) during the same months.
Near the ELA (ETH Camp), the albedo is much higher in June and increases at Carrefour and Summit. From June to July, the albedo decreases more at Camp IV than at ETH Camp and at Carrefour. Around the Arctic Circle and near the ELA (Gimex-FUA; Henneken and others, 1994), the albedo is similar to the observations at ETH Camp. In the dry-snow zone (site II; 2128 ma.s.l.), the albedo is larger than at Carrefour which is located in the percolation zone. For August, only measurements at ETH Camp are available, which show larger values compared to June and July due to the beginning of the accumulation season. It is obvious that the beginning of the accumulation season in mid-August will be responsible for increasing the albedo much more in the ablation than in the accumulation area. Measurements near the ELA on the ice cap of Devon Island show a seasonal trend similar to that obtained at ETH Camp but with a time lag of 1 month. At ETH Camp, the albedo decreases by 0.14 from May to July and increases strongly in August, whereas at Ice Cap Station there is also a drop of albedo from June to July and an increase in August. In general, the albedo for June and July is lower than 0.60 in the ablation area, a drop to $0.70-0.75$ around the ELA (because of the longer duration of the snow cover), reaches $0.80-0.85$ in the percolation zone and $0.85-0.90$ in the dry-snow zone. According to Holmgren (1971), the albedo at the ELA far north is a little higher (0.01-0.03)

Table 4. Comparison of monthly mean values of albedo for various study sites referred to in the text. The number in brackets represents the number of days taken into account

\begin{tabular}{lcccc}
\hline Location & May & fune & July & August \\
\hline Summit GRIP) & & $0.91(17)$ & & \\
Site II & & & $0.86(26)$ & \\
Carrefour & $0.80(17)$ & $0.83(30)$ & $0.80(27)$ & \\
Gimex-FUA & & $0.70(27)$ & \\
ETH Camp & $0.86(21)$ & $0.76(50)$ & $0.72(59)$ & $0.79(55)$ \\
Camp IV & & $0.63(30)$ & $0.50(31)$ & \\
Gimex-IMAU & $0.88(11)$ & $0.86(30)$ & $0.75(31)$ & $0.81(31)$ \\
Ice Cap Station & & & & \\
\hline
\end{tabular}


in May, July and August, but much higher $(0.10)$ in June compared to ETH Camp. Albedo observed in July at the ELA increases from Gimex-FUA to ETH Camp and to Ice Cap Station.

Measurements of longwave radiative fluxes are very rare and were made only at Camp IV, Carrefour, Summit and ETH Camp. $L W_{\text {net }}$ is treated as residual $\left(L W_{\text {net }}=N R-S W_{\text {net }}\right)$ at Gimex-FUA and site II. In the percolation and dry-snow zone, $L W_{\text {net }}$ is between -33 and $-45 \mathrm{~W} \mathrm{~m}^{-2}$ in June and July. At Camp IV, $L W_{\text {net }}$ is in the same range, while the values at ETH Camp are about $-55 \mathrm{~W} \mathrm{~m}^{-2}$. If $L_{\mathrm{o}}$ at Camp IV were recalculated using Equation (4), the value of $L W_{\text {net }}$ would decrease by $7 \mathrm{~W} \mathrm{~m}^{-2}$ and the discrepancy in the $L W_{\text {net }}$ would diminish greatly. $L W_{\text {net }}$ obtained originally at Gimex-FUA $\left(-72 \mathrm{~W} \mathrm{~m}^{-2}\right)$ is $20 \mathrm{~W} \mathrm{~m}^{-2}$ smaller than at ETH Camp. Applying the correction for the possible underestimation of measured net radiation developed at ETH Camp (Equation (4)), $L W_{\text {net }}$ shows $-57 \mathrm{~W} \mathrm{~m}^{-2}$ at Gimex-FUA. With these assumptions, the likely values of $L W_{\text {net }}$ for the three stations near the ELA came closer to each other. It seems that $L W_{\text {net }}$ is larger in the upper accumulation area due to a smaller difference between atmospheric and surface temperature. At the ELA and in the ablation area, $L_{\mathrm{o}}$ is larger compared to $L_{\mathrm{i}}$. Closer to the coast, $L_{\mathrm{i}}$ is affected by low clouds which influence the amount of $L W_{\text {net }}$ more than higher up on the ice sheet. Therefore, $L W_{\text {net }}$ depends mainly on the variation of $L_{\mathrm{o}}$ and on lowcloud conditions.

A comparison of screen-level temperature and surface temperature measured by radiometers is given in Table 5 for Summit, Carrefour, Camp IV and ETH Camp. The temperature gradient in May is much larger at Carrefour than at ETH Camp, which could be explained by the lower temperature of the interior snow cover. Similar values for June and July at Carrefour were observed in May and June at ETH Camp. This indicates a time lag of approximately 1 month for Carrefour compared to the present site. At Summit, the temperature is much lower for the measuring period but the temperature gradient between the surface and screen-level height is similar to observations at Carrefour. Values for July at Camp IV are in the same order as at ETH Camp, whereas the temperature gradient for June is much larger. Monthly mean air temperatures are similar and the discrepancy is caused by the much lower surface temperature. No reasonable explanation could be found for this fact.

As in the case of longwave radiative fluxes, measurements of net radiation are rare in space and time for the Greenland ice sheet. The amount of net radiation decreases from the ice margin to the accumulation area and shows its largest values in July. The decrease of net radiation from the ELA to the upper accumulation area is much smaller than from the ablation area to the ELA. A profile of net radiation from west to east at $70^{\circ} \mathrm{N}$ shows $90 \mathrm{~W} \mathrm{~m}^{-2}$ for the upper ablation area, $35 \mathrm{~W} \mathrm{~m}^{-2}$ for ELA, $25 \mathrm{~W} \mathrm{~m}^{-2}$ for the percolation zone and around zero $\mathrm{W} \mathrm{m}^{-2}$ for the dry-snow zone. This feature is caused by the variation in albedo and $L_{0}$. Values at ETH Camp $\left(37 \mathrm{~W} \mathrm{~m}^{-2}\right)$ and Gimex-FUA $\left(38 \mathrm{~W} \mathrm{~m}^{-2}\right.$, adapted) are similar for July. It seems that this amount of net radiation can be expected at the ELA between $67^{\circ}$ and $70^{\circ} \mathrm{N}$.

\section{CONCLUSIONS}

At the study site near the mean equilibrium-line altitude in midwest Greenland, an energy gain of the surface due to radiative fluxes can be expected from the end of May to the middle of August with a mean value of $32 \mathrm{~W} \mathrm{~m}^{-2}$ for

Table 5. Comparison of monthly mean screen-level temperature $\left(T_{\mathrm{a}}\right)$ and surface temperature $\left(T_{\mathrm{s}}\right)$ measured by radiometers for Summit, Carrefour, Camp IV and ETH Camp. Unit: ${ }^{\circ} \mathrm{C}$

\begin{tabular}{llrrrr}
\hline & & May & June & July & August \\
\hline \multirow{2}{*}{ Summit } & & & & & \\
& $T_{\mathrm{a}}(1991)$ & - & -13.4 & - & - \\
Carrefour & $T_{\mathrm{s}}(1991)$ & - & -16.5 & - & - \\
& $T_{\mathrm{a}}-T_{\mathrm{s}}$ & - & 3.1 & - & - \\
& $T_{\mathrm{a}}(1967)$ & -15.7 & -10.0 & -5.5 & - \\
Camp IV & $T_{\mathrm{s}}(1967)$ & 5.9 & 2.9 & 1.6 & - \\
& $T_{\mathrm{a}}-T_{\mathrm{s}}$ & - & -0.9 & 1.4 & - \\
& $T_{\mathrm{a}}(1959)$ & - & -4.1 & -0.8 & - \\
ETH Camp & $T_{\mathrm{s}}(1959)$ & - & 3.2 & 2.2 & - \\
& $T_{\mathrm{a}}-T_{\mathrm{s}}$ & - & -0.5 & 0.5 & -3.5 \\
& $T_{\mathrm{a}}(1990)$ & - & 1.4 & 1.8 & -4.2 \\
& $T_{\mathrm{s}}(1990)$ & -1.9 & -0.9 & 0.6 & -1.8 \\
& $T_{\mathrm{a}}-T_{\mathrm{s}}$ & -11.5 & -2.6 & -1.7 & -3.1 \\
& $T_{\mathrm{a}}(1991)$ & 2.9 & 1.7 & 2.3 & 1.3 \\
& $T_{\mathrm{s}}(1991)$ & - & -0.7 & 0.6 & -2.7 \\
& $T_{\mathrm{a}}-T_{\mathrm{s}}$ & - & -2.3 & -1.5 & -3.7 \\
& $T_{\mathrm{a}}(1990-91)$ & - & 1.6 & 2.1 & 1.0 \\
& $T_{\mathrm{s}}(1990-91)$ & & & & \\
\hline
\end{tabular}


this period. During the melt period, the lack of global radiation caused by a larger cloud amount is compensated for by an increase in longwave incoming radiation. Due to the steady values of longwave outgoing radiation, net radiation at the surface is characterized mainly by the albedo (with a mean value of 0.75 ) and its variation. Measurements of shortwave reflected radiation during pre- and post-melt seasons derived from a high tower provided more reasonable data for remote-sensing applications over a wide flat snow area, because the effect of surface undulations (small sastruga) and lower solar elevation can be diminished.

Due to a possible underestimation of net radiation measured with a net radiometer, it is recommended that the single components of the radiation balance are measured using the shading method. Especially at locations with high surface reflectivities, an underestimation of net radiation leads to a large relative error, which corresponds, in terms of melt rate, to the order of mean annual accumulation at the present site.

\section{AGKNOWLEDGEMENTS}

The present work was financed by the Eidgenössisches Techniche Hochschule (ETH), Zürich (grant Nos 0-20013-90 and 0-40-040-90) and the Swiss National Foundation for Scientific Research grant Nos 2127449-89, 20-32649-91 and 81EZ-039069). The authors are extremely grateful to all the people who joined the ETH Greenland Expedition. We should like to thank the GRIP Steering Committee, the Alfred-Wegener-Institut für Polar- und Meeresforschung (AWI) in Bremerhaven and the Danish Meteorological Institute in Copenhagen for their generous support at Summit.

\section{REFERENCES}

Abe-Ouchi, A., H. Blatter and A. Ohmura. 1994. How does the Greenland ice sheet geometry remember the ice age? Global and Planetary Change, 9 $1-2), 133-142$.

Ambach, W. 1963. Untersuchungen zum Energieumsatz in der Ablationszone des grönländischen Inlandeises (Camp IV-EGIG, $69^{\circ} 40^{\prime} 05^{\prime \prime}$ N, $49^{\circ} 37^{\prime} 58^{\prime \prime}$ W). Medd. Gronl., $174(4)$.

Ambach, W. 1974. The influence of cloudiness on the net radiation balance of a snow surface with high albedo. f. Glaciol., 13 (67), 73-84.

Ambach, W. 1977. Untersuchungen zum Energieumsatz in der Ablationszone des grönländischen Inlandeises: Nachtrag. Medd. Gronl., $187(5)$.

Ambach, W. und G. Markl. 1983. Untersuchungen zum Strahlungshaushalt in der Akkumulationszone des grönländischen Inlandeises. Medd. Gronl., $187(6)$.

Braithwaite, R.J. and O.B. Olesen. 1985. Ice ablation in West Greenland in relation to air temperature and global radiation. Z. Gletscherkd. Glazialgeol., 20, 1984, 155-168.

DeLuisi, J., K. Dehne, R. Vogt, T. Konzelmann and A. Ohmura. 1993. First results of the baseline surface radiation network (BSRN) broadband infrared radiometer intercomparison at FIRE II. In Keevallik, S. and O. Kärner, eds. Current problems in atmospheric radiation. Proceedings of the International Radiation Symposium, Tallinn, 1992. Hampton, VA, A. Deepak Publishing, 559-564.

Diamond, M. and R. W. Gerdel. 1958. Radiation measurements on the
Greenland ice cap. International Association of Scientific Hydrology Publication 46 (General Assembly of Toronto 1957 Snow and Ice), 403 426.

Drummond, A.J. 1956. On the measurements of sky radiation. Arch. Meleorol. Geophys. Bioklimatol., Ser. B, 7, 413-436.

Fröhlich, C. and J. London. 1986. Revised instruction manual on radiation instruments and measurements. WMO Rep. 149. (World Climate Research Programme (WCRP) 7.

Halldin, S. and A. Lindroth. 1992. Errors in net radiometry: comparison of six radiometer designs. 7. Atmos. Oceanic Technol., 9, $762-783$.

Henneken, E.A.C., N.J. Bink, F.F. Vugts, F. Cannemeijer and A. G. C. A. Meesters. 1994. A case study of the daily energy balance near the equilibrium line on the Greenland ice sheet. Global and Planetary Change, 9 (1-2), 69-78.

Holmgren, B. 1971. Climate and energy exchange on a sub-polar ice cap in summer. Arctic Institute of . North America, Devon Island Expedition 19611963. Part E. Radiation climate. Uppsala, Uppsala Universitet. Meteorologiska Institutionen. (Meddelanden 111.)

Huybrechts, P., A. Letréguilly and N. Reeh. 1991. The Greenland ice sheet and greenhouse warming. Palaeogeogr., Palaeoclimatol., Palaeoecol., $89(4), 399-412$.

Kneizys, F.X. and 7 others. 1988. Users' guide to LOWTRAN7. Bedford, MA, Air Force Geophysics Laboratory. Environmental Research Papers 1010.

Konzelmann, T. and R.J. Braithwaite. 1995. Variations of ablation, albedo and energy balance at the margin of the Greenland ice sheet, Kronprins Christian Land, eastern North Greenland. f. Glaciol., 41(137), 174-182.

Konzelmann, T., R. S. W. van de Wal, W. Greuell, R. Bintanja, E. C. A. Henneken and A. Abe-Ouchi. 1994. Parameterization of global and longwave incoming radiation for the Greenland ice sheet. Global and Planetary Change, 9(1-2), 143-164.

Laternser, M. 1991. Surface morphology. In Omura, A. and 8 others. Energy and mass balance during the melt season at the equilibrium line altitude, Paakitsoq, Greenland ice sheet. Zürich, Swiss Federal Institute of Technology, 17-20. (ETH Greenland Expedition. Progress Report 1.

Liljequist, G.H. 1956. Energy exchange of an Antarctic snow-field: short-wave radiation (Maudheim $71^{\circ} 03^{\prime} \mathrm{S}, 10^{\circ} 65^{\prime} \mathrm{W}$ ). NorwegianBritish-Swedish Antarctic Expedition, 1949-52. Sci. Results, 2(1A).

Müller, G. and A. Ohmura. 1993. Radiation annual report ETH, No. 2, 1990 and 1991. Zürcher Geographische Schriflen 52.

Oerlemans, J. and H. F. Vugts. 1993. A meteorological experiment in the melting zone of the Greenland ice sheet. Bull. Am. Meteorol. Soc., 74 (3), 355-365.

Ohmura, A. 1987. Heat budget of the climate system between the last glacial maximum and the present. University of Tokyo. Department of Geography. Bulletin, 19, 21-28.

Ohmura, A. and N. Reeh. 1991. New precipitation and accumulation maps for Greenland. J. Glaciol., 37 (125), 140-148.

Ohmura, A. and K. Schroff. 1983. Physical characteristics of the Davostype pyrradiometer for short- and long-wave radiation. Arch. Meteorol. Geophys. Bioklimatol., Ser. B, 33, 57-76.

Ohmura, A. and 8 others. 1991. Energy and mass balance during the melt season at the equilibrium line altitude, Paakitsoq, Greenland ice sheet. Zürich, Swiss Federal Institute of Technology. (ETH Greenland Expedition. Progress Report 1.)

Ohmura, A., P. Kasser and M. Funk. 1992a. Climate at the equilibrium line of glaciers. 7. Glaciol., $38(130), 397-411$.

Ohmura, A. and 10 others. 1992b. Energy and mass balance during the melt season at the equilibrium line altitude, Paakitsoq, Greenland ice sheet. Zürich, Swiss Federal Institute of Technology. (ETH Greenland Expedition. Progress Report 2.)

Ohmura, A. and 6 others. 1994. Energy balance for the Greenland ice sheet by observation and model computation. International Association of Hydrological Sciences Publication 223 (Symposia at Yokohama 1993 - Snow and Ice Covers: Interactions with the Atmosphere and Ecosystems), 85-94.

Warren, S. G. 1982. Optical properties of snow. Rev. Geophys. Space Phys., 20 (1), 67-89.

Warren, S.G., C.J. Hahn and J. London. 1985. Simultaneous occurrence of different cloud types. 7. Climate Appl. Meterol., 24, $658-667$. 